\title{
Heritage Churches as Post-Christian Sacred Spaces: Reflections on the Significance of Government Protection of Ecclesiastical Heritage in Swedish National and Secular Self-Identity
}

By Tobias Harding

\begin{abstract}
Sweden is often described as a country where secularization has come comparatively far. At the same time, state and church have remained relatively close, especially before the enactment of the decisions of increased separation of church and state in 2000. Sweden is also a country where the built heritage of the established church enjoys a strong legal protection. When relations between the state and the established church were reformed in 2000, this protection was left in place. This article offers an analysis of the significance ascribed to ecclesiastical heritage in the form of Church of Sweden heritage churches in government policy, focusing on the process leading up to the separation of church and state in year 2000. Using Mircea Eliade's understanding of the sacred and the profane as a starting point for my analysis, I contextualize the significance of heritage churches is in the wider context of a post-Christian, and more specifically post-Lutheran, secularized society. I suggest that the ongoing heritagization of Church of Sweden's church buildings could be seen as a process where they are decontextualized from the denominationally-specific religiosity of the Church of Sweden, but rather than being re-contextualized only as secular heritage, they could be more clearly understood as becoming the sacred places, and objects, of a post-Lutheran civil religion and generalized religiosity, i.e. not simply a disenchantment, but also a re-enchantment. This could be understood as a continuation of traditions of approaching memory, and the sacred, developed in a society characterized by the near hegemony of the established church in the religious sphere, but also in partially counter-clerical movements, such as the Romantic movement.
\end{abstract}

Keywords: sacred and profane, sacred places, heritagization, secularization, post-Christian, post-Lutheran, religious heritage, heritage policy, Sweden.

Harding, Tobias: "Heritage Churches as Post-Christian Sacred Spaces: Reflections on the Significance of Government Protection of Ecclesiastical Heritage in Swedish National and Secular Self-Identity", Culture Unbound, Volume 11, issue 2, 2019: 209-230. Published by Linköping University Electronic Press: http://www.cultureunbound.ep.liu.se 
The Swedish parish churches constitute a cultural heritage built over a period of nearly a millennium. There are over 3000 church buildings, representing the architecture, building history, and building technologies of numerous epochs. Church interiors and objects are, taken together, a cultural treasure, which, in richness and scope, surpasses what is collected in Swedish museums.

The church buildings represent fundamental aspects of Swedish social, economic and political history. From medieval to modern times, the parish has been the framework of local society (Ministry of Culture 1994: 125).

What happens to the symbolical buildings of traditional religion in the process of secularization? Sweden is often seen as a country where secularization has gone comparatively far. Only a minority of its inhabitants believes in God in a traditional manner, and religious references play a comparatively limited role in public discourse. At the same time, Sweden is a country where a majority of the population has chosen to remain members of the Church of Sweden, a historically established church (Thurfäll 2015, Bromander 2013, cf. Taylor 2007), and where the state and the established church have remained close, especially until the increased separation of church and state in 2000. It is also a country where the physical heritage of the established church, in the form of church buildings and churchyards, enjoys a strong legal protection (Harding 2016a). When the reform of relations between the Church of Sweden and the state, which took place in 2000, was prepared, there appears to have been a broad consensus that this protection should remain. This was, for example, made clear by the government report that started the process in 1994, as illustrated by the quote above, favorably comparing this national cultural heritage to that preserved in the country's museums. So far, heritage churches has remained a category specifically protected by heritage law, with legal regulation protecting all churches built for the established national church before 1940, and used by it up to 2000, even after equal treatment of religious denominations became enshrined in the fundamental law (cf. Harding 2016a).

This article offers an analysis of the significance ascribed to ecclesiastical heritage in the form of Church of Sweden heritage churches in government policy documents, focusing on the process leading up to the separation of church and state in year 2000, and on the on reasons given for continuing to prioritize protecting and preserving ecclesiastic heritage specifically in the form of heritage churches. The article thus ads to the growing bodies of research focusing on the complex relation between secular and sacred created through the process of secularization (e.g. Casanova 1994, 2014, Sundback 2007, Josephson-Storm 2017, Taylor 2007, 
Thurfell 2015, Burén 2015), and on the roles played by heritage in general, and religious heritage in particular, in late-modern societies (e.g. Nora 1998, Paine 2013, Sullivan 2015, Wangefelt Ström 2011, Hillström, Löfgren \& Wetterberg 2017, Harding 2016b, 2018).

The article focuses on official documents, such as government bills and government reports, published after 1988 in the process leading up the increased separation of church and state in 2000 . The significance ascribed to heritage churches in these documents is contextualized in the wider context of a post-Christian secularized society, which is described on the basis of previous research and illustrated with statements made by, among others, then-prime minister Göran Persson, and traced further back in 20th century Swedish history. It is analyzed with a focus on how these churches are understood as post-Christian sacred spaces, suggesting that there is a connection between the way in which secularization has developed in Sweden, and the high priority so far given to its ecclesiastical heritage in the form of Church of Sweden heritage churches. The article is limited by its focus on how the government relates to such heritage churches, even though it also includes examples and descriptions of cultural and ideological movements in Swedish society in order to contextualize these policies. The article opens by discussing the central theoretical concepts used in the analysis: sacred and secular, secularization, and post-Christian, in relation to religious heritage. It then continues with an analysis of the main ways in which churches and ecclesiastical heritage were understood when the separation of church and state was prepared, tracing these ways of understanding it backwards through the history of Swedish heritage and Church policies in the 20th century, and offering some reflections on current developments in the significance of heritage churches in Sweden.

\section{Central Concepts}

'Sacred' and 'secular' are closely related terms, often defined as opposites, but often also viewed as defining each other. The notion of sacredness has long been a central concept in understanding the roles played by religion and ritual in societies. For the purposes of this article, the idea of sacred spaces becomes a central aspect of the sacred. In a sacred space, behavior, for those who accept it as sacred, is guided by other norms than those guiding behavior in other places. The sacred space has ritual meaning, often representing the general order of the cosmos, as understood by believers. In his classical work The Sacred and the Profane, Mircea Eliade (1961) draws examples of the cultural differentiation between these two spatial categories from a large number of cultures and religious traditions. Among these examples is that of a church in a Western city: 
For a believer, the church shares in a different space from the street in which it stands. The door that opens on the interior of the church actually signifies a solution of continuity. The threshold that separates the two spaces also indicates the distance between two modes of being, the profane and the religious. The threshold is the limit, the boundary, the frontier that distinguishes and opposes two worlds - and at the same time the paradoxical place where those worlds communicate, where passage from the profane to the sacred world becomes possible. (Eliade 1961: 25)

Eliade argues that time is understood differently in sacred spaces, that it is one of the functions of religious ritual to transport the participant out of the everyday experience of time and space, reconnecting her, or him, to mythical time:

Just as a church constitutes a break in plane in the profane space of a modem city, the service celebrated inside it marks a break in profane temporal duration. It is no longer today's historical time that is present, the time that is experienced, for example, in the adjacent streets, but the time in which the historical existence of Jesus Christ occurred, the time sanctified by his preaching, by his passion, death, and resurrection. (Eliade 1961: 72)

From this perspective, sacred space is not only characterized by ritual behavior, but also constituted by it. In the case of Sweden, churches until year 2000 legally became classified as such - and thus also legally protected as heritage - through the performance of the sacralization ritual prescribed in the liturgy of the Church of Sweden. Conversely, they could also cease to be legally classified as church buildings through a desacralization ritual. After 2000, legal protection of these churches as built heritage concerns church buildings constructed before 1940, and owned by the Church of Sweden in 2000, a status based on their historical building date and legal status, regardless of any religious rituals that may occur today (Government of Sweden 1998: 134f).

Understanding the world less as a sacred cosmos, and more through the framework of a non-religious, or disenchanted, worldview is often viewed as a central aspect of the process of secularization (Weber 1993, Taylor 2007). Other central aspects observed by the Canadian philosopher Charles Taylor are a decline in personal belief in the divine, and the increased separation of the social and institutional spheres of the state and of religious organizations (Taylor 2007). These aspects of secularization do not always coincide, and the process of secularization has taken significantly different paths in various societies, creating dif- 
ferent understandings of the meaning of secular society. The Nordic societies of North-Western Europe are today characterized by a very low level of belief in the God of the traditional Evangelical-Lutheran religion, and public discourse is not to any high degree characterized by direct references to religion, but the spheres of church and state have remained close (Casanova 2014), as exemplified by the above mentioned legislation on church buildings.

While belief in God is not particularly high in the Nordic countries, it can be argued that what has truly increased is not atheism in a strict sense, but rather a more vague belief in "something", or even in a "God", but in a more vague sense than when understood from a strict, or traditional, theological perspective. It has also been observed that culture and life in present day Swedish society still retains many characteristics reminding us of its Christian and, specifically, Lutheran past; such as its calendar, public celebrations and holidays, as well as many traditions celebrated publicly, or in private. In this sense, e.g. Christian symbolism and ways of understanding time lives on in how the year is structured, within an otherwise secular understanding of the world (Thurfjell 2015, Burén 2015, cf. Assmann 2011). In order to emphasize such characteristics, such societies can be described as 'post-Christian', i.e. as a society which understands itself as secular, and which contains members from a multitude of religious backgrounds, but which, at the same time, has a number of characteristics in its self-understanding and cultural organization which are the recognizable results of its Christian history (cf. Thurfell 2015, Burén 2015, Moberg 2013). Similarly, a society could be described as 'post-Lutheran' if these characteristics have their background in a specifically Lutheran spirituality. As illustrated by the case of Sweden, secularization does not necessarily mean that all religious institutions or denominations disappear from public life. There are, in fact, many examples of the contrary, and it has been argued that increased separation of church and state frees religious denominations to act more independently in the public sphere (Casanova 1994, 2014).

In the context of cultural heritage, museums and heritage sites have often been understood as secular spaces, sometimes even as metaphorical 'secular temples' filling a role in the context of secular ideologies and national communities similar to that of holy sites (cf. Duncan 1995, Bennett 1995, Nora 1998). Much like sacred spaces, heritage sites can be understood as enabling people to reach out to a different time than that of the surrounding world, albeit to historical time rather than to the sacred time invoked in religious buildings. The heritagization of sacred objects and spaces can thus be understood as a secularization, changing how the religious building is understood; from sacred space to heritage site (cf. Bennett 1995, Paine 2013, Koselleck 2004, Nora 1998). This process has been compared to the reinterpretation, or removal, of Catholic symbols in Swedish churches during the reformation, as well as to other reinterpretations of religious sites and objects 
during changes in official religion (Wangefelt Ström 2006, 2011). Common to these processes is that they are all processes of reinterpretation and domestication, where religious objects are reinterpreted within the context of a new dominant worldview; be it a different religious interpretation, or that of secular historicism. Today, there are also many cases of the opposite process to that of religious sites being reinterpreted as heritage, e.g. museums starting to treat religious objects with a greater respect for the religious understanding of them, or even adopting some of the ritual respect which according to religious communities should be paid to certain objects (Paine 2013, Sullivan 2015). As this article will further illustrate, the categories of heritage spaces and sacred spaces are often less separate from each other than was previously assumed.

\section{Churches as Heritage in Sweden}

The current heritage protection regime in Sweden can be traced at least back to the statute protecting government-owned heritage buildings introduced in 1920 (SFS 1920:744). This regulation has later been complemented with legislation protecting privately owned buildings. The current heritage law dates from 1988, and combines these areas of heritage protection (SFS 1988:950, Government of Sweden 1987). All church buildings and churchyards belonging to the established church - the Church of Sweden - became automatically protected under the rules for government owned heritage buildings included in the 1920 heritage statute, and continued to be protected under the 1988 Heritage Law, with one major change; only churches built before 1940, and owned by the Church of Sweden, would now enjoy this protection. Newer churches would not. The difference was explained as follows in the government bill proposing the legislation to parliament:

Considering, among other things, the historical importance of churches as the heart of the parish, and as examples of the architecture of times past, most of our older churches have to be recognized as being of great importance from the standpoint of cultural history. [...] When the construction of churches increased again, in the 1950's, the character of the churches had changed in a way that motivates my proposal to abolish the requirement of government permission for the construction of new churches. Most churches constructed after 1939 are also different when compared to churches in a traditional sense (Government of Sweden 1987: 57).

Both around 1920 and in 1988, the suggestion had been made that individual churches should be judged on their importance as cultural heritage, but on both 
occasions the government chose automatic protection without selection, since it was assumed that the vast majority of churches would be judged important enough to protect (Government of Sweden 1987, cf. Ministry of Ecclesiastic Affairs 1922, Wetterberg 1992, 2011, Hillström 2017). The central reasons for the continued protection of ecclesiastical heritage given in 1988 were all mentioned in the government bill quoted above; churches were preserved for their significance to local identity, and for their value as historical documentation. These aspects were also viewed as highly related (cf. Harding 2018). In the fundamental goals of Swedish cultural policy laid down in the cultural policy bill of 1974, the government had argued that the presence in landscapes and cityscapes of tangible evidence of the history of the place was necessary for the well-being of the people who lived there:

When the individual $[\ldots]$ is deprived of his connection backwards in time, his feelings of insecurity and alienation grows. The preservation of historical continuity in the physical cultural environment is thus of fundamental importance to the individual's feeling of security and anchoring in existence. (Government of Sweden 1974: 301)

The local church as a symbol of historical continuity, on both the local and the national levels, was already a long established concept in Sweden. Several heritage policy documents had already used this argument (e.g. Ministry of Ecclesiastical Affairs 1922, Ministry of Education 1972), and more would use it later (e.g. Government of Sweden 1987, Government of Sweden 1995, Ministry of Culture 1995, Government of Sweden 1996, cf. Harding 2018). It can be traced at least back to the turn of the century (Harding 2016b).

While local identity had already been linked to the parish churches in the early 20th century, this connection at that time also included the relation between national and religious identity. The role of the Church, as well as of physical churches and of other heritage buildings, had been central to the nationalist movements of the late $19^{\text {th }}$ century and early $20^{\text {th }}$ century. This was especially true of the Young Church Movement (Sw: "ungkyrkorörelsen"), which can, in this context, be understood as the explicitly Christian side of a larger nationalist trend in Swedish society, and thus more concerned with churches than nationalism in general. The Young Church Movement emphasized the role of the Church of Sweden as the institutionalization of the Christian faith in Sweden, and the imagined community of the Church as close to identical to that of the Swedish nation, aiming to revitalize this side of national identity, thus leading the nation back to its Christian roots. This connection between the Church as a community of faith, and the nation as an ethno-cultural community, has almost never been referred to in official discourse 
on churches as heritage since the mid- $20^{\text {th }}$ century, but it played a significant role in such discourses in the early $20^{\text {th }}$ century. This connection was also intrinsically linked to the previously mentioned focus on local identity; local parish churches had been viewed as symbols of the idealized local rural communities that were now imagined as the site of an idealized authentically Swedish culture that had preceded the present urbanization and industrialization. To the Young Church Movement, this image had been one of an organic community of Christianity and Swedish culture (Blückert 2000, Sundeen 2008, Harding 2016b, Tergel 1974). These views can be illustrated by the following lines from the hymn "Church of the Fathers" (Sw: "Fädernas Kyrka"), which was a central symbol in the Young Church Movement.

Firmly she is founded by the hand of the Lord, Built to be his temple in the North.

All was consecrated in the embrace of the Church:

The bridegroom's vow to his bride,

The home, the newborn's Christian name,

The warriors' voyage to the last haven,

The banner and the garb of the King.

(Den svenska psalmboken 1937: 154f)

This passage emphasizes the metaphorical and physical church as the sacred space where important events in the life of the individual, as well as in that of the nation, are ritually marked and sanctified (Eckerdal 1988, Blückert 2000, Harding 2016b). The church is made to simultaneously represent both, the mytho-historical time of church ritual and the Bible, and the Christian history of Sweden, merging the two into an organic unity.

In later heritage policies, understanding Swedish history as one of a culturally and religiously homogeneous agrarian society has become a dominant way of narrating Swedish history, but it has often been combined with a narrative of secularization, in which this historical society is contrasted with the post-World War II modern and secular welfare state, thus establishing modern Swedish secular identity as the successor to a homogeneously religious one (cf. Harding 2007, Hyltén-Cavallius \& Svanberg 2016). This narrative can also help us understand the change in heritage legislation from general automatic protection of church buildings to protecting only the pre-War churches. While the pre-War churches could symbolize pre-modern Sweden, the newer churches were seen as parts of the present, otherwise secular, modern welfare state. As such, they carried no more significance than other buildings, and there was thus no reason for them to be protected under other criteria than those for heritage status for other buildings 
(cf. Government of Sweden 1987:57, quoted earlier in this article, Harding 2018). After the separation of church and state in 2000, the separation between the secular current age and the religious heritage of pre-industrial society has become institutionalized as the separation between the religious neutrality of the state, and its role in preserving the religious heritage of the past. As expressed by the latest Government Bill on Cultural Heritage:

In the tangent of a clearer separation between the state and the Protestant church, lies an important symbolic and cultural change in the view of what belongs to society as a whole. The ecclesiastical cultural heritage has evolved during nearly a millennium, and through the position of the Church in society, the ecclesiastical cultural heritage has become a significant part of the history of the country. This situation remains regardless of the organizational state of affairs that this heritage, due to the change of relations, has now, to a large extent, come to be administered within the private sector. (Government of Sweden 17: 41f)

\section{The Church, the Nation, and the (Social) Democratic State}

While the old identification of church and nation has now been relegated to being a relation to the Lutheran history of the nation, views of the Church of Sweden as ideally open to the entire people of Sweden has remained relevant in the self-understanding of the Church in the form of the concept of the Church as a Folk Church, or "people's church", i.e. as an institution ideally open to the entire people of the nation. As such, the Folk Church could be said to build on ideas once common in the Young Church Movement, and in that context related to its largely ethno-cultural understanding of the national community (Blückert 2000). During the $20^{\text {th }}$ century, the concept has, however, developed to become more closely related to civic concepts of nationality, including a view of democratic participation in the government of the Church which is largely parallel to notions of democratic participation in Swedish national democracy. The Folk Church could thus be viewed as a parallel to the $20^{\text {th }}$ century vision of the welfare state as a folkhem, a "people's home" where the state would care for the welfare of the people (Claesson 2004, Blückert 2000, Harding 2016b). Just like the folkhem, the Folk Church could be said to have moved from an ethno-cultural understanding of the nation and its people, towards a more civic one where the people is understood as a collective of citizens (or church members, in the case of the Folk Church), but still retaining some of its original ethno-cultural, and patriarchal, characteristics (cf. Lagergren 1999, Berggren \& Trägårdh 2015). 
In the 1990s, when the separation of church and state was being prepared, it appears that the democratically elected leadership of the church, its clerical leadership, and a majority of the national parliament already agreed that a separation of church and state was desirable. Yet there were also dissenting voices. The last leading politician to oppose the separation of church and state was probably Göran Persson, who was, ironically, the Prime Minister under whose leadership the separation would be enacted, after the decision had been made in the months before his election to leader of the Social Democrats, and his appointment to Prime Minister in 1996 (Ekström 2003). When he later discussed the issue in his autobiography - as the first political issue he mentions there - his argument focused not on Christianity, but on the church as a place, and as an institution, to which each citizen can turn when his, or her, needs are spiritual, rather than material; a spiritual counterpart to the material welfare offered by the state, but also an institution manifesting the national community, much as it had been at the beginning of the $20^{\text {th }}$ century:

The Church is our Swedish Folk Church, in the best possible meaning of that word. All of us should have a right to gather there. When life sometimes chooses a direction with consequences that we might not be able to carry on our own, all of us should be welcome to the Church. Such things happen to everyone, many times in a lifetime [...].

In my view, the separation of the Church of Sweden and the state started a movement away from the public and towards the private. [...] This development might have come anyway, but it has definitely been expedited by the separation of the Church from the state. As to the costs for cultural heritage, i.e. campaniles and church buildings, the state - i.e. all Swedish taxpayers - is likely to end up paying anyway. (Persson 2008: 20f)

Even to Persson himself, this feeling of community now appeared to have become a part of the past, but as a part of the nation's cultural heritage it remained a government responsibility. His memoirs also give as an example of a view of what the church, and its immediate surroundings, can mean to modern Swedes, as a sacred place and a refuge of tranquility, in the context of late-modern Swedish society:

After the election [of 1998], I took my refuge in the Northern Cemetery in Stockholm. There, I appeared able to find peace and tranquility in the incredibly tense situation in which I found myself. This appears to 
have been the Monday after the election, possibly the Tuesday. I felt like the cemetery offered fresh air and inspiration, which should tell you something about my state of mind. [...]

Cemeteries are often beautiful. Their tranquility speaks to me. The Northern Cemetery in Stockholm possesses both, beauty and peace, it is a gigantic area with many interesting tombstones. I found myself walking around aimlessly, hunting for a specific gravestone. I was looking for the name 'Per Albin Hansson', the Social Democratic prime minister who had coined the concept of the Folkhem. (Persson 2008: 197)

In this passage, Persson treats the cemetery in a way resembling what Eliade (1961) describes as a 'sacred space', a space separate from the profane world surrounding it. It becomes a space for thought and contemplation, where he can reflect on a future course of action. At the same time, the emphasis is not on the church as a house of God, but on the cemetery as a physical manifestation of historical memory, where he can seek inspiration not from God, but from his political predecessors. In a similar fashion, Persson discusses the Church as an institution where the people, individually and collectively, can seek solace at times of individual or national tragedy or crisis, such as after the shipwreck of MS Estonia in 1994, or the discotheque fire which killed or injured 263 people in Gothenburg in 1998 (Persson 2008). This understanding appears to be deeply rooted in a society where the 'standard' schema for understanding the sacred remains based in a Christian tradition, even though this tradition is present in daily life only in the form of seemingly secular traditions, such as holiday celebrations, or ceremonies connected to major life events (cf. Thurfjell 2015, Burén 2015). This could be seen as a parallel to what Michael Billig (1995) refers to as 'banal nationalism, i.e. everyday reminders of national belonging, e.g. in the forms of national sports teams of national weather maps, which still serves to reinforce the national identity for each individual, so that this identity can be re-actualized in times of crisis.

Interestingly, viewing churches and cemeteries as generalized post-Christian sacred spaces, decoupled from their denominational context and viewed as heritage, at least as much as they are understood specifically in the context of Christianity, is an understanding with many historical parallels, to the Romantic movement of the 19th century, as well as to the attempts of early Social Democrats to relate their vision to earlier concepts of religion and the nation. Person's understanding of churches has parallels in statements made by earlier Social Democratic politicians in Sweden. It has, for example, much in common with the following thoughts presented by Arthur Engberg, who was the Minister of Ecclesiastical Affairs in the first stable Social Democratic governments of the 1930's. These remarks were 
part of a radio speech he made in 1942, and framed as a reflection on the poem "The Image of the Madonna in Heda" (Sv. "Himladrottningens bild i Heda") by the Swedish national-romantic poet Verner von Heidenstam (1915):

The world of tradition is the world of devotion. There, we approach the personalities of the past. There, whispers voices from the graves. There, live story and memory. Family, neighborhood and people meet us. [...] We become a link in a development which has started before us and which will continue after us. [...] There, they made their deeds, their joys and their sorrows, fought and suffered. [...]

The bridge between us and the powers of life, between us and what we hold sacred, is thus not knowledge. It is not a work of thought or science. It is life, faith, piety, and devotion. (Engberg 1945:292f)

Engberg takes the poem, in which a young poet converses with a Medieval image of the Madonna, as the starting point for a reflection on tradition and spirituality. Much like Persson, Engberg viewed the church and its heritage as a context via which it is possible to gain a personal relation to the past, to the struggles of past generations, and by which it becomes possible to understand the present, including issues of identity and politics. He also does so in a context where he views the struggles of humanity both, as an object of reverence and as an expression of spirituality, which can be accessed through heritage, and perhaps especially by heritage with a specifically religious, or spiritual, subject. As such, churches and cemeteries may be viewed not only as Christian, or specifically Lutheran, sacred spaces, but also as post-Christian, post-Lutheran, sacred spaces for devotion in a generalized spirituality, where the sacred place connects the visitor not so much to the time of the historical Christ, but to the flow of history in general, and in particular to the early times of the particular church building.

Quite appropriately, the line from von Heidenstam's poem which Engberg took as the title for his radio speech was "Den har tro för vilken mycket är heligt", i.e. "He has faith for whom much is sacred". Engberg had started as an anti-clerical and outspokenly atheist socialist politician and writer, but with time turned into one of the builders of the Social Democratic welfare state in general, and of its politics on education, culture, and the Church, in particular. While he continued to argue for retaining government control over the Church of Sweden, he also appears to have come to embrace a generalized romantic spirituality (cf. Harding 2015, Harding 2016b). During World War II, he apparently found the combination of von Heidenstam - then still viewed as something of a national poet (cf. Nyblom 2008) - and ecclesiastical heritage to be an appropriate symbol for a contemplative 
speech to the public on how all our works build upon those of our forefathers, and on how true spirituality is found not in dogma, but in the contemplation of art, nature, and heritage. Sixty-five years later, Persson would not have been likely to refer to von Heidenstam in this way, but as we have seen, he otherwise professed to be drawn in a similar way to ecclesiastical heritage, using it and its connection to previous leaders of his party and the nation, as a starting point for planning the future of the country. At least, this is how he chose to present the scene in his memoirs, symbolically indicating the profoundness of the situation.

\section{Ecclesiastical heritage, religion, and post-Christianity}

Since 2000, the Church of Sweden is legally a part of the Third Sector, rather than a state church, and the state aims to stay neutral and uninvolved in relation to the religious activities if the Church, as well as to treat all religious denominations equally, if not identically (Harding 2016a). At the same time, the ecclesiastical heritage of the Church of Sweden remains protected in law, and described in government bills and reports as something that it is a government priority to preserve and maintain accessible for the entire population. The Folk Church ideal of openness can thus be said to have been transferred from the religious mission of the Church to its ecclesiastical heritage, at least in the eyes of the state. Documents, such as the government bill proposing to separate church and state, define this heritage in a relatively open manner:

This is a living cultural heritage, which for many centuries has been continuously used, and is still used, for the same purpose. It is also a cultural heritage which is accessible for everyone, regardless of, for example, religious affiliation, age, sex, and citizenship. Everyone is able to experience the church buildings and their interiors as historical and antiquarian monuments, take part of art and architecture, listen to church music, or seek a moment of peace and tranquility. [...] It is of great importance that this common cultural heritage is preserved for future generations. (Government of Sweden 1998: 134)

As we can see in this quote, the concept of cultural heritage has been extended to include a number of other values than that of documenting history, or even that of reinforcing identity (Harding 2018). This extension has some basis in the general development of heritage policy in Sweden, as well as in international developments in the heritage and museum sector. In the 1950's, Swedish heritage policy had already started to extend its protection from individual buildings to entire milieus (Ministry of Justice 1956). In the latest government bill on heritage 
protection, the government proposes to specifically include vegetation in the protected heritage of churchyards and cemeteries (Government of Sweden 2017). The bill on the state and the Church of Sweden, quoted above, appears to include not only activities such as religious music in the protected heritage, somewhat in the style of UNESCO's views on protection for intangible heritage (cf. UNESCO 2003, e.g. Smith \& Akagawa 2009), but also the continued use of church buildings for religious purposes.

More than anything, the quote appears to focus more on the visitor's experience of the building than on its documentary value. This experience is described as including not only the historical aspects of ecclesiastical heritage, but also aesthetic aspects, as well as experiences of 'peace and tranquility', i.e. an almost - or actually - spiritual aspect of the experience of entering a church. It is easy to get the impression that the government bill describes experiences like those Eliade (1961) associated with entering a sacred space, and similar to those associated with ancient churches by Engberg and Persson. Yet, what is being described here are activities for which churches, with the financial support of the state, should continue to be accessible to all, regardless of religious affiliation, even after the change of relations between church and state, and considered to be in line with an interpretation of the freedom religion which was considered to preclude the existence of an established church (Government of Sweden 1998, Harding 2016a). This apparent paradox could be understood in the context of post-Christian Sweden, and its understanding of the concepts of 'religion' and 'Christianity'. According to religious studies researcher David Thurfjell (2015), the term 'Christianity' is now generally perceived as referring only to a strict understanding of the religion; someone who believes in all of the ethical and theological claims ascribed to it. Many people in Sweden do not identify as 'Christian', even though they appear to hold more diffusely religious, or spiritual, beliefs (Thurfjell 2015, Burén 2015).

According to a survey made in 2012, around 45 percent of the Swedish population answer that they believe in God, a figure that appears to be relatively stable (Bromander 2013). In 2005, 53 percent believed in "a kind of spirit or life force" (Thurfjell 2015: 25). Considering that in 2012, 67.5 percent of the population were members of Church of Sweden (Svenska kyrkan 2019), it has to be assumed that many of those holding more generally spiritual beliefs also remain members of the Church of Sweden. Surveys made by the Church of Sweden reach results that point in the same direction. In 2015, 67 percent of the respondents of a member survey stated that they are members of the Church in order to be able to celebrate church ceremonies, such as baptisms, confirmations, weddings, and funerals, i.e. to celebrate ceremonies marking important life events in the context of the liturgy, and in church buildings. In the same survey, 53 percent stated that they had attended such ceremonies during the past year, while 60 percent had visited cemete- 
ries. This could be compared to the 26 percent who had attended a regular church service during the past year. In the same survey, 47 percent stated that they were members so that the churches themselves could be preserved, and 44 percent that they consider their membership a part of their Swedish identity. Only 28 percent were members because they viewed themselves as Christian, although 45 percent stated that it was so that Sweden would continue to be a Christian country (statistics from Church of Sweden).

Even though many people in Sweden do not view themselves as Christians, or even as religious, their understanding of the spiritual appears to be shaped by a history where Christianity, in the form of the Lutheranism of the established church, has been the normative understanding of religious practice and belief, and where religious life has been shaped around that church (Thurfell 2015, Burén 2015). The connection between church membership and national, as well as local, identity remains strong. In 1998, policy makers appear to still have associated churches not only with experiences of history and aesthetic values, or with the specific creed of the Church of Sweden, but also with feelings of 'peace and tranquility', a place representing spirituality and historical continuity, sheltered from the turmoil of the world. This 'sacred space' (cf. Eliade 1961) should not become the property of one single religious denomination. While churches in $2000 \mathrm{did}$ literally became the property of Church of Sweden parishes (Harding 2016a), the state took it upon itself to continue to guarantee that heritage churches, including all churches built before 1940, were preserved and remained accessible for the public.

\section{Concluding Reflections}

It has often been claimed that we see a process where religious objects and sites are heritagized, and through this process secularized: religious objects and buildings become seen as historical monuments and museum pieces, rather than as sacred objects and places. Yet, it has also often been observed that there are similarities between the norm-prescribed approach of museum and heritage audiences to the displayed objects, and the prescribed venerating attitude expected of a religious worshiper approaching a sacred object or place. It is not only the case that churches are becoming increasingly museum-like, it is also that museums have always had similarities with sacred places.

Based on the examples in this article, I suggest that the ongoing heritagization of Church of Sweden's church buildings could also be seen as a process where they are decontextualized from the denominationally specific religiosity of the Church of Sweden, but rather than being re-contextualized only as secular heritage, they could be more clearly understood as becoming the sacred places and sacred ob- 
jects of a post-Lutheran civil religion and generalized religiosity, i.e. not simply as a disenchantment, but also as a re-enchantment. People come to churches to contemplate heritage, spirituality, and aesthetics, as well as to celebrate life events, often without making a difference between secular and religious categories. This approach could be understood as a continuation of traditions of approaching memory and the sacred, developed in a society characterized by the near hegemony of the established church in the religious sphere, but also in partially counter-clerical movements, such as the Romantic movement (including, e.g. von Heidenstam). It is not only an example of heritage and religion coexisting in the same spaces, but of the close relationship and strong similarities between these two categories. While many visitors to Swedish churches may seek to experience both spirituality and history, the separation of church and state requires both state and Church to separate religion and heritage, even when both the state and the Church appears to want to take responsibility for aspects which could be described as spiritual.

How things will develop in an increasingly multi-religious society, where only a shrinking part of the population can be expected to identify with the formerly established church, or that church with the nation, remains to be seen. The part of the population who regularly participates in church services has remained relatively constant throughout the $20^{\text {th }}$ century (cf. Thurfell 2015: 23, Bromander 2013), but membership in the Church of Sweden continues to shrink. Today, non-Lutheran figures, such as the Dalai Lama, appear to be at least as adapted to function as symbols of generalized post-Lutheran spirituality as representatives of the Church of Sweden (cf. Thurfjell 2015). While only a small portion of the Swedish people view themselves as Lutherans, or even as Christians, many more remain members of the Church of Sweden, often specifically in order to have access to church buildings and the ceremonies performed there. Representatives of all political parties continue to support ecclesiastical heritage in the form of Church of Sweden heritage churches as a major part of Swedish protected heritage, to which all should have equal access. It would appear that Sweden, both as a society and as a state, remains post-Lutheran, at least in its understanding of the churches that are preserved as the heritage of the established church that has dominated Swedish understanding of spirituality since the Middle Ages (first as a part of the Catholic Church, and later as a Lutheran national church). In other policy areas than heritage policy, the Swedish state has made attempts to offer equal opportunity to other religious denominations (Harding 2013). Comparing the corresponding efforts made to include the heritage of other religions in government-protected heritage of Sweden to the understandings of ecclesiastical heritage discussed in this article, will have to be the subject of a different article. The analysis presented here suggests that such a comparative study could have much to say about how religion and identity are understood and presented in Sweden today. 
By understanding the relationship between heritage and sacrality better, scholars could better understand the roles played by religious heritage, as well as of heritage in general, in post-Christian, or otherwise secularized, societies. It would appear that heritage sites can function in ways similar to those of religiously sacred spaces, in that they are approached as spaces separate from the surrounding contemporary mundane world. In the case of Swedish heritage churches, this appears to be the case regardless of whether the separate time of these spaces is understood as relating to the history of the particular church building, or to the mytho-historical sacred time of the Christian revelation, or simultaneously to both , understanding local history in the context of Christian history, or Christian history in the context of the history of the local or national community. It is also worth noting that several of the policy documents quoted in this article view it as especially important that religious activities have continued in these churches continuously throughout their history (Government of Sweden 1998: 134). While church buildings are no longer legally constituted as such through the performance of specific liturgies, there is still a liturgical performative aspect of the heritage value in that the continued performance of religious activities is considered to contribute to it.

This article has approached these issues from the vantage point of a post-Lutheran state where state and church have been closely connected for a long period of time, and where official recognition of religious pluralism has come relatively late. It is likely that the similarities will be larger in countries with a similar history, such as other Nordic countries, Estonia, or the Protestant parts of Germany. There may also be parallels to the developments described in this article in other countries where secular modernity has become central to identity, and is often understood in contrast to a historical condition which is understood as religiously homogeneous, but where the ties between the state and religious institutions remain. In countries where the secular state has a history of conflict with religious institutions, such as France or Turkey, identification may have developed differently, as would likely be the case in the religious landscape of the United States. Yet, post-Christian religiosity and civil religion has now emerged, at least to some degree, in most countries traditionally dominated by Christianity, and religious heritage continues to play a significant role, both in nationally protected cultural heritage and in national identity all over the world.

Tobias Harding is the professor of cultural policy and cultural organization at University of South-Eastern Norway. He is the author of a number of articles, chapters, and books on cultural policy and heritage policy. He is particularly interested in the institutionalization of values and notions of identity in such policies. E-mail: tobias.harding@usn.no 


\begin{abstract}
Acknowledgments
The research presented in this paper has been made possible thanks to funding from the Swedish Research Council (Vetenskapsrådet) for the research project 'How the Church of Sweden was Transformed into a National Cultural Heritage' (dnr 2013-1908). My thanks to my colleagues in that project, in the RHiT research network, and the anonymous reviewers assigned by this journal. My thanks to Veronika Possek, for editing this article, and to Pernilla Jonsson at the Central Office of the Church of Sweden, who helped with statistical information.
\end{abstract}

\title{
Notes
}

${ }^{1}$ All quotes from Swedish sources have been translated by the author of this article.

${ }^{2}$ According to a major survey conducted in 2012, 19 percent of the Swedish population "prayed to God" at least once a month, 8 percent participated in Church services, 45 percent said that they believed in "God", but 78 percent were members of religious organizations (Bromander 2013). The same year 67.5 percent were members of Church of Sweden (Svenska kyrkan 2019).

${ }^{3}$ Swedish laws and statutes are referenced with their number in the official SFS series, including year of publication and number

${ }^{4}$ For a more in depth discussion of Sweden as a Folkhem (people's home) and the Church of Sweden as a Folk Church (people's church), see e.g. Claesson 2004, Blückert 2000, and Harding 2016b. Blückert discusses this with a focus on the ethno-national aspects of the 'folk' of the Folk Church. See also Lagergren 1999, for a discussion of similar aspects of the 'folk' of the Folkhem state. Claesson (2004) analyses the influence of Harald Hallén, a theologian, Church of Sweden cleric, and Social Democrat politician, on the development of the concept of the Folk Church in a less ethno-national and more civic direction. The relationship between conceptions of the Church, heritage, and the nation in Sweden in the Interbellum years is also something that I discussed somewhat more in depth in an article in 2016 (Harding 2016b).

${ }^{5}$ In the election of 1998, the governing Social Democrats lost a significant number of seats in parliament, forcing them to make new alliances in order to stay in power (which they did, with the support of the Left Party, and the Green Party).

${ }^{6}$ For a discussion of Engberg's influence on Swedish cultural policy, see Harding 2015. ${ }^{7}$ If translated focusing on the literal meaning, rather than on poetic aspects, the more relevant lines of von Heidenstam's poem reads as follows:

"Eight hundred Christmas nights,

I saw light their candles.

Child, hear what I tell,

kings kissed my feet.

Forgotten I sit, coated in dust. 
Do not pray for what you love, not for gold, nor for name.

Go, denier!

Only for those who have faith, miracles happen.

[...] I prayed

Give me the golden heart

give a drop of the good,

loving humility,

which, forgotten and without name,

carved and crowned thee,

tall and stern on the queenly throne.

Let me revere and sing to

the great, bright world [...]

He has faith for whom much is sacred."

(translated from Heidenstam 1915).

${ }^{8}$ Respondents could choose more than one alternative from a list of 15 alternatives. Other listed alternatives included "take part in other activities offered by the Church of Sweden", "other people need the Church of Sweden", "my life should have a spiritual dimension", "continuing a family tradition", "supporting the international aid work of the Church of Sweden", "the Church of Sweden is an important voice in public debate", "I have not yet gotten around to leave", "I have good experiences with the Church of Sweden", "I have not thought that much about my membership" (statistics from Church of Sweden).

\section{References}

Assmann, Aleida (2011): Cultural Memory and Western Civilization: Functions, Media, Archives. Cambridge: Cambridge University Press.

Bennett, Tony (1995): The birth of the museum: History, theory, politics. London: Routledge.

Berggren, Henrik \& Trägårdh, Lars (2015): Är svensken människa? Gemenskap och oberoende i det moderna Sverige. 2nd ed. Stockholm: Norstedts.

Billig, Michael (1995): Banal Nationalism. London: Sage.

Blückert, Kjell (2000): The Church as Nation: A Study in Ecclesiology and Nationhood. Frankfurt: Peter Lang.

Bromander, Jonas (2013): "Religiositet i Sverige",Lenart Weibull, Henrik Oscarsson \& Annika Bergström (eds.) Vägskäl. Göteborg: Göteborgs universitet, SOM-institutet, 291-301.

Burén, Ann af (2015): Living Simultaneity: On religion among semi-secular Swedes. Huddinge. Södertörns Högskola.

Casanova, José (1994): Public religions in the modern world. Chicago, IL: University of Chicago Press.

Casanova, José (2014): "Two dimensions, temporal and spatial, of the secular: comparative reflections on the Northern Protestant and Southern Catholic perspectives 
from a global perspective", Rosemarie van den Breemer, José Casanova \& Trygve Wyller (eds.) Secular and sacred? The Scandinavian case of religion in human rights, law and public space, Göttingen: Vandenhoeck \& Ruprecht, 21-33.

Claesson, Urban (2004): Folkhemmets kyrka. Harald Hallén och folkkyrkans genombrott, En studie av socialdemokrati, kyrka och nationsbygge med särskild hänsyn till perioden 1905-1933. Uppsala: Acta Universitatis Upsaliensis.

Den svenska psalmboken (1937): Uppsala: Svenska kyrkan.

Duncan, Carol (1995): Civilizing Rituals: Inside Public Art Museums. London: Routledge.

Eckerdal, Jan (1988): “'Fädernas kyrka' och Guds: Kyrkosyner i Svenska kyrkans psalmböcker", Svensk teologisk kvartalsskrift, 1988:64, 112-129.

Ekström, Sören (2003): Makten över kyrkan, om Svenska kyrkan, folket och staten. Stockholm: Verbum.

Eliade, Mircea (1961): The Sacred and the Profane. The Nature of Religion. New York: Harcourt, Brace \& World.

Engberg, Arthur (1945): "Den har tro för vilken mycket är heligt", Arthur Engberg. Tal och skrifter III. Stockholm: Tiden, 287-294.

Government of Sweden (1974): Proposition 1974:28. Om kulturpolitik. Stockholm: Riksdagen.

Government of Sweden (1988): Proposition 1987/88:104. Om kulturmiljövård. Stockholm: Riksdagen.

Government of Sweden (1995): Proposition 1995/96:80. Ändrade relationer mellan staten och Svenska kyrkan. Stockholm: Riksdagen.

Government of Sweden (1996): Proposition 1996/97:3. Kulturpolitik. Stockholm: Riksdagen.

Government of Sweden (1998): Proposition 1998/99:38. Staten och trossamfunden: begravningsverksamheten, kulturminnena, personalen, avgiftsbetalningen, m.m. Stockholm: Riksdagen.

Government of Sweden (2017): 2016/17:116. Kulturarvspolitik. Stockholm: Riksdagen.

Harding, Tobias (2007): Nationalising Culture: The Reorganization of Swedish Cultural Policy 1970-2002. Linköping: Linköping University.

Harding, Tobias (2013): "Faith-Based Organizations and the Secular State: The Establishment of a Muslim Study Association in Sweden", Journal of Muslim Minority Affairs, 33:3, 341-355.

Harding, Tobias (2015): "Bildning as a Central Concept in the Cultural Policy of the Swedish Government - From Arthur Engberg to Alice Bah Kuhnke" in Nordic Journal of Cultural Policy, 2015:2.

Harding, Tobias (2016a): "From State Church to Third Sector Organization? The Separation of Church and State in Sweden", International Society for Third-Sector Research Working Paper Series X, Baltimore, MD: ISTR.

Harding, Tobias (2016b): "The Dawn of the Secular State: Heritage and Identity in Swedish Church and State Debates 1920-1939”. International Journal of Cultural Policy. 22:4, 631-647.

Harding, Tobias (2018): "Preserving Churches for Future Generations: Central Values in Swedish Policies on Church Heritage", Nordic Journal of Cultural Policy, 1:21, $5-24$.

Heidenstam, Verner von (1915): Nya dikter. Stockholm: Bonniers.

Hillström, Magdalena (1917): "Staten, kyrkan och ansvaret för kyrkobyggnaderna", 


\section{Culture Unbound}

Journal of Current Cultural Research

Magdalena Hillström, Eva Löfgren \& Ola Wetterberg (eds.) Alla dessa kyrkor: Kulturvård, religion och politik. Göteborg: Göteborgs universitet.

Hillström, Magdalena, Löfgren, Eva \& Wetterberg, Ola (eds.) (2017): Alla dessa kyrkor: Kulturvård, religion och politik. Göteborg: Göteborgs universitet.

Hyltén-Cavallius, Charlotte \& Svanberg, Fredrik (2016): Älskade museum: Svenska kulturhistoriska museer som kulturproducenter och samhällsbyggare. Stockholm: Nordic Academic Press.

Josephson-Storm, Jason A. (2017): The Myth of Disenchantment: Magic, Modernity, and the Birth of the Human Sciences. Chicago: University of Chicago Press.

Koselleck, Reinhart (2004): Futures Past: On the Semantics of Historical Time. New York: Colombia University Press.

Lagergren, Fredrika (1999): På andra sidan välfärdsstaten, En studie i politiska idéers betydelse, Eslöv: Brutus Östlings bokförlag, Symposion.

Ministry of Culture (1995): Kulturpolitikens inriktning. SOU 1995:84. Stockholm: Fritzes.

Ministry of Ecclesiastic Affairs (1922): Betänkande med förslag till lag angående kulturminnesvård samt organisation av kulturminnesvården. SOU 1922:11-12. Stockholm: Centraltryckeriet

Ministry of Education (1972): Samhälle och trossamfund. SOU 1972:36. Stockholm: Beckmans tryckerier.

Ministry of Justice (1956): Byggnadsminnen. SOU 1956:26. Stockholm: Victor Pettersons bokindustri.

Ministry of Public Administration (1994): Staten och trossamfunden. SOU 1994:42. Stockholm: Fritzes.

Moberg, Jessica (2013): Piety, Intimacy and Mobility: A Case Study of Charismatic Christianity in Present Day Stockholm. Huddinge: Södertörns Högskola.

Nora, Pierre (1998): "The Era of Commemoration", Pierre Nora (ed.) The Construction of the French Past: Realms of Memory. Volyme III: Symbols. New York: Colombia University Press, 609-637.

Nyblom, Andreas (2008): Ryktbarhetens ansikte: Verner von Heidenstam, medierna och personkulten i sekelskiftet Sverige. Stockholm: Atlantis.

Paine, Crispin (2013): Religious Objects in Museums: Private Lives and Public Duties. London: Bloomsbury.

Persson, Göran (2008): Min väg, mina val. Stockholm: Bonniers.

SFS (Svensk författningssamling) 1920:744. Kunglig Maj:ts kungörelse med föreskrifter om det offentliga byggnadsväsendet. Stockholm: Riksdagen.

SFS (Svensk författningssamling) 1988:950. Kulturmiljölag. Stockholm: Riksdagen.

Smith, Laurajane \& Akagawa, Natsuko (2009): Intangible Heritage. New York: Routledge.

Sullivan, Bruce M. (ed.) (2015): Sacred Objects in Secular Spaces: Exhibiting Asian Religions in Museums. London: Bloomsbury.

Sundback, Susan (2007): "Membership in Nordic 'National' Churches as a 'Civil Religious' Phenomenon", Implicit Religion, 10:3, 262-280.

Sundeen, Johan (2008): Andelivets agitator: J.A. Eklund, kristendomen och kulturen. Lund: Minerva och Högskolan i Borås.

Svenska kyrkan (2019): "Svenska kyrkans medlemsutveckling år 1972-2017”, document downloaded from the Church of Sweden website, www.svenskakyrkan.se (accessed 02/05/19). 


\section{Culture Unbound}

Journal of Current Cultural Research

Taylor, Charles (2007): A Secular Age. Harvard: Harvard University Press.

Tergel, Alf (1974): Från konfrontation till institution. Ungkyrkorörelsen 1912-1917. Stockholm: Verbum.

Thurfjäll, David (2015): Det gudlösa folket. De postkristna svenskarna och religionen. Stockholm: Molin \& Sorgenfrei.

UNESCO (2003): Convention for the Safeguarding of the Intangible Cultural Heritage.

Wangefelt Ström, Helena (2006): "Kulturarv: Ikon för en sekulariserad tid", Kulturella perspektiv - Svensk etnologisk tidskrift, 15:3, 67-76.

Wangefelt Ström, Helena (2011): "Heligt, hotfullt, historiskt: Kulturarvifieringen av det katolska i 1600-talets Sverige", Lychnos, 2011:29-53.

Weber, Max (1993): The Sociology of Religion. Boston: Beacon Press

Wetterberg, Ola (1992): Monument och miljö: Perspektiv på det tidiga 1900-talets byggnadsvård i Sverige. Göteborg: CTH.

Wetterberg, Ola (2011): "Conservation and the Professions: The Swedish Context 1880-1920", Melanie Hall (ed.) Towards World Heritage: International Origins of the Preservation Movement 1870-1930. Surrey: Ashgate, 201-220. 